\title{
The Information (Society) Race
}

\author{
László Z. KARVALICS \\ Information Society and Trend Research Institute, \\ Technical University Budapest \\ $<z k l @ i t m . b m e . h u$
}

"This is the source of a paradox in dealing with the information society: it is simultaneously a sociological adventure and a daily strategic challenge, an anthropological promise and a raw commercial reality, a chance to improve the quality of life and an economic battle which hinges on gaining competitive advantage."

\begin{abstract}
This paper sets out to analyze the information competition element. Prior to a review of the roots and of the two parts of the current intensifying information society race, we will take a look at the historic prelude, the functioning of some pre-information societies - that is to say we will glean from the patterns of the making of competitive advantage in information among nations from the early high cultures to the middle of the $20^{\text {th }}$ century. As a "prehistory", we will outline the emergence of the information society and its development into a competition problem: principally the movement of the American-Japanese tandem (1961-1978) and the pursuing bunch (1978-1991). And finally, we will analyze the decade (1992-2002) of comprehensive national information strategies, demonstrating that in the measurable domain of the information society there really are winners and losers: systematic information society development programs have tangible outcomes. The gap is widening, and the developed countries are winners every time. We can observe the real information society race taking place between them.
\end{abstract}

Key words: Information society, communication technology, history, competition 


\section{INTRODUCTION}

When illustrating the strategic stake of the "information society" many people refer to the 1996 report of IDRC (International Development Research Center). The authors of this report claim that, in the next 25 years, nine (!) out of the leading fifteen economies of our present world will fall back to the level of developing economies due to the lack of their ability to assimilate the knowledge and know-how necessary for the new communication environment. This is a challenge, others perceive, which is similar in nature to the historical relocation of the commercial routes from the Mediterranean Sea to the Atlantic Ocean. [Paquet-Sévigny, 1997]

Even if, being in possession of other data, we doubt this twister-like, rank-smashing force, it seems certain that the transformations attributed to the information society environment today demonstrate no feature or subfield, the analysis of which would permit us to ignore the economic/commercial facet. In the meantime, our thinking is strongly bounded by the fact that we want to measure the transforming reality of the present in the light of the idealized order of the future as it relates to timeless social philosophical axes. This is the source of a paradox in dealing with the issue (or most recently: discipline) of the information society: it is simultaneously a sociological adventure and a daily strategic challenge, an anthropological promise and a raw commercial reality, a chance to improve the quality of life and an economic battle which hinges on gaining competitive advantage. That's why the term "Information Society" could become a simple rhetoric phrase, if we confuse these two aspects, and use the neutral, future-oriented everyday meaning instead of the competitionbased strategic meaning. (We have chosen the term "race" instead of the simple "competition" to recall this negative allusion.)

Many people tend to smile upon the United States for its politicians' and pedagogues' hysterical reactions to just a few percentage-points fall in the success of American scientific education or to a slow decrease in students' relative performance in international student competitions and comparative analyses, despite the country's tower high and undoubted leading position in the information and knowledge economy. And however loud journalists may laugh at the millions of dollars spent to reverse the trend, calling these hopeless efforts a Mission Impossible, we are currently on the front line of the information society race. Strategic sensitivity enhances a sense of danger, the awareness of danger causes a pressure to act, the recognized challenge lets the field reach priority in policymakers' heads. The Clinton administration made education a question of national security since 1998, however, with this step it only followed the course of the "information highway program" launched in 1993 (attributed to Albert Gore ever since), 
which was in fact a disguised support of the world market competitiveness of the American information industry.

This is not the place to give a full, systematic and detailed historical overview $^{1}$ : this is but an introductory collection of examples to show the existence and abundance of those (currently) recognized information patterns. We choose not to include the fostering of information competitiveness within one state (empire or community), the information games between opposing groups, or the historical forms of information monopolies, since the close relationship between methods, professional institutions and IT-solutions chosen for the individual tasks would require common discussion in the case of another approach. Similarly, let us omit the lessons drawn from the cultural history of military and diplomatic intelligence. Instead we will focus on the amplification of the economicsocial potential through a consciously planned internal information system aimed directly or indirectly at generating competitive advantage.

\section{HISTORICAL PRELUDE:}

\section{gleaning from patterns of information competitiveness as generated among nations from the early high cultures to the middle of the $20^{\text {th }}$ century}

The "extension of the communicative action" is dealt with in the sense of "objectivation", the development of systems for temporary external storage and retrieval in the literature. ${ }^{2}$ Yet innovations in information technology can also be deduced from the relations between space (physical and communal space) interconnected by communication and the time needed to carry out the connecting operations, as H.A. Innis convincingly demonstrated at the beginning of the 1950s [Innis, 1950, 1951]. In early imperial structures, it is very interesting, for example, to survey the osmosis of the ephemeral sets of texts and meanings, referred to as "tradition" between generations, and their code-storage media. However, the conjunctive tissues of communication within empires and the guarantee of their stability in the face of rival empires were provided by consciously developed fundamental systems of information infrastructure - the information metabolism of these societies, including the institutional forms of information production (academia), storage (library) and dissemination (communication, education).

First of all, the professional news and postal service, which turned from heralds to carrier-pigeon networks as the fastest way to deliver written records (up to the middle of the $19^{\text {th }}$ century). The news and message household of Egypt and Mesopotamia involved carefully organized, 
painstakingly maintained and controlled channels. Fai sát, the highly efficient postal service of the New Empire era delivered such a great number of letters that the Pharaoh was actually required, by law, to get up early in order to read them all. A Chinese organization based on post-houses managed by the central and local powers could make the multipoint-tomultipoint sign-stream seamless in a similar way. The Persian and Roman Empires also used legendarily effective and prioritized background news industries. The medieval rebirth of the postal service, together with the cyclic financing failures accompanying its development, retrospectively outline the rhythm that led from the recognition of challenges stemming from outside pressures to an increase in the recognized demand for interior communication performance. The distinguished role of the news service, which was supported by investment or resource redeployment and transitionally handled as a priority to address this challenge $\mathrm{e}^{4}$, lapsed at the very moment when the outer pressure was relieved and the resources were needed in other subsystems. The effectiveness of the postal service reached its peak just at the time other new (partly rival) information channels (the telegraph and the telephone) were beginning to expand at the end of the $19^{\text {th }}$ century.

Claude Chappe's semaphore visual telegraph, a great experiment by postrevolutionary France, and one in which the French government invested heavily, came a generation before the later wire communication systems, similar to the way Minitel preceded the Internet, and remained a truncated torso in infrastructure history, likewise due to the slow adoption of more advanced new solutions. Indeed, it was the United States that began to write the next chapter of communication history with the development of its telegraph network, running parallel to transcontinental railways this system surpassed any other similar efforts both in pace and density. ${ }^{6}$ In the next wave, at the outset of the construction of telephone networks, the champion riders of development were the free market in the Anglo-Saxon world and private enterprise, which embarked on network-building with single concession holders in other places. Meanwhile, in Germany it was the government that put itself at the head of the telephone program ${ }^{7}$ - taking economic and administrative-political considerations into account.

The pace made by government and market forces in the wake of these developments can probably be best demonstrated in action in connection with the building of radio broadcasting networks ${ }^{8}$, that great infrastructure adventure of the third decade of the $20^{\text {th }}$ century. If we examine the list giving the number of radio transmission stations for each individual country in 1929 (Table 1), we can see that out of the top twenty nations in the current Information Society rankings, only Singapore, Taiwan and Israel are missing. This is no surprise, since none of these small nations existed as 
independent states at that time! In other words, the "top twenty" of the present day is practically the same as seventy years ago!

Another prominent field of fundamental information infrastructure is the library/record office/archives complex, which has, in addition to its administrative-supporting role, ever since Assur-ban-apli's great library in Nineveh, also been based on programs of knowledge accumulation. The competition between Hellenistic successor states (especially Alexandria and Pergamum) for the title of 'the richest library' also resurfaces in the neverending rivalry between Italian city-states and humanistic courts. The knowledge revolution of the Renaissance emerged in its own era as luxury production and consumption, established on deep economic foundations. Directly alongside the gunpowder of philology, translated literature and the textual traditions of antiquity, this first "information boom" placed the cartridge-fuse of printing. It was able to become a generator of competitive advantage because, with its reviving fresh new waves, it created a widening transformational starting point toward technological innovation. The $15-17^{\text {th }}$ centuries are those of Cardano, Leonardo and Galilei, and thus of Italy while in Holland and England the next power/political paradigm is impending through the revolution of, among other things, public libraries. ${ }^{9}$

The libraries, of course, were merely "tools" serving the experts, the real vehicles of knowledge. The actual track for racing has always been these specialists (scholars, artists, diplomats, generals) and the knowledge that could be acquired through them in the form of technology transfer. The race run for the leading position in libraries still remained a friendly game compared to the unceasing battle fought for thinking people and the rush of experts (monks, students) sent abroad to study [Dedijer, 1968]. Korean specialists for example were sought after so much that one aim of Japanese campaigns and pirate attacks was just to kidnap craftsmen. (Even during the 1592-1598 war when the Japanese army invaded Korea, thousands of craftsmen were dragged to Japan). When we recall the nearly 2500 -year-old story, in which the luckier ones from among those countries that contended to give shelter to the scholars hounded out by Euergetes II from the library of Alexandria, were able to launch nothing less than a knowledgeavalanche, we cannot help but recognize the fact that the United States, the great winner of the current information society race, came into possession of an exorbitant intellectual capital in the shape of immigrant Europeans, a phenomenon it repeated in several waves: after the period of pioneers, during the great immigration waves in the last third of the $19^{\text {th }}$ century and in the early $20^{\text {th }}$ century, then throughout the migration of the scientific elite of the period between the two world wars. We should not either forget that the production value of "...18 million German settlers was ten times higher than that of Marshall Aid [Kopátsy, 1989]." 
Among the tools for the indigenous growth of knowledge capital, those processes seem the most interesting in which a nation/state could gain advantage either by a planned competitiveness program or as a nondeliberate effect of a related development. In Italy, for example: those contuberniums and sodalitas (the ancestors of later academies) that were established as "school literary and debating societies" consisting of 4-8 humanist scholars, helped the scholars in their own professional progress, explicitly developing the idea of lifelong learning. ${ }^{10}$ Scholars with academic experience then became "goods" in demand throughout Europe - emperors stood in line to "hire" a well-known mastermind. Independent states in the middle of the $17^{\text {th }}$ century, on the other hand, realized that, after a lot of little private academies, it was high time to establish the single, great national academy and, while constantly keeping an eye on their "rival's" academies, they set up these institutes following each other's example.

A similar "evolutionary" logic made French engineers (especially building engineers) much in demand from the end of the $18^{\text {th }}$ century. From the middle of the century, Daniel-Charles Trudaine's central "drawing bureau" in Paris, recognizing that better jobs require higher qualifications, launched a special course for the best designers, led by one of the bureau's excellent engineers. This course developed into the École des Ponts et Chaussées, the ancestor of all later technical universities. Since these highly qualified students of the school, who therefore became much sought after and marketable, learned far more than they actually needed for their work, their unemployed "scientific valence" made them the ideal professional audience for the emerging new natural sciences.

The deliberate use of organized public education as an internal resource may date back a long time in history. "It was called into life and maintained by the need to train an administrative and military elite for a prolonged period, from ancient scrivener training to the hyper-specialized Sparta. The real sign of the competition factor appears with the rivalry of the slowly secularizing universities. ${ }^{12}$

In Japanese history, the political revolution that brought about the fall of the Tokugawa Shogunate, inaugurating an era of major political, economic and social change known as the Meiji period (1868-1912) gave the country compulsory education, which led to practically full-scale literacy by the end of the century. Most historians agree that the spectacular economic growth that modernized Japan, a land lacking natural resources, can primarily be traced to that country's investment in human knowledge resources. Similarly, historians claim the most important factor explaining the remarkably successful transformation of the structure of Danish agriculture in the last century, was in fact the cultural "deep ploughing", based on compulsory education and people's academies, which "produced" highly 
qualified and creative agriculturists, who remain to date the foundation of Danish welfare. We can also mention the offensive development strategy of Hungarian public education in the last third of the $19^{\text {th }}$ century, which, for a long period, enjoyed the support of increasing budgetary subsidies, fixed in law by the parliament.

Among national programs for the accumulation of knowledge, Korea deserves a prominent position. In 1443, during the reign of Sejong, scholars of the royal academy developed Hangul (han'gul), an easy and effective phonetic system for writing the Korean language, considered one of the most scientific alphabets in use in any country. Before the introduction of simple phonetic symbols Koreans used Japanese symbols. However, these could only become the treasure of a few privileged aristocrats, due to the amount of time needed to acquire them. The original name of Hangul (hunmin csong-um meaning 'appropriate voices to educate the people') also indicates that it was developed as a tool directed from above to democratize knowledge. The easy-to-learn-and-apply alphabetic system consisting of 24 letters, including 14 consonant and 10 vowel symbols, contributed largely to a high level of literacy among Korean people and to advanced printing later on (while today it is also easily applicable in computer systems).

The above snapshot from cultural history convincingly justifies the argument that government-led efforts to generate competitive advantage show a wide variety of forms even in pre-information periods - and that such solutions will find and take their place (with a subtle shade of flush on their cheeks) in a new world economic environment.

\section{PREHISTORY:}

\section{the information society emerges and becomes an issue of competition, the American-Japanese tandem (1956-1978), and the new competitors (1978-1991)}

Tadao Umesao, a professor at Kyoto University, was the first to express the coming of the "information society" in his 1963 forecast expressing the economic headway made in the information sector. By that time, as we now know, the number of people employed in information-related jobs in the United States had long surpassed the magic 50 percent. In addition to its leading position in perceived world rankings in wired telephony, radio and television, the United States had just begun to forge ahead in content industry (mainly in the field of motion picture, animation, and rock music), and the competition takeover in the scientific research and university-based education industries was also close to coming to an end (pushing the formerly dominant British-German continental axis off the track for good). 
In addition to these, the emerging computer industry also counted as an almost exclusively American "terrain".

That was the situation in which Japan, frenzied by the success of its modernization cycles, conducted by government resources under a plannedeconomy-like discipline, embarked upon such strategic developments as would promise comprehensive growth along the triangle of IT penetration/media consumption/industrial expansion. And though the results of these programs appeared (and will appear) to have shifted in time, by the beginning of the $70 \mathrm{~s}$ they had provided Japan with a prominent role, as a sort of "re-versioner", yet one who after all still does not disturb the clear American supremacy. It is therefore not by chance that when the AmericanJapanese invitational conference was held at the Washington University, Seattle, in 1978, aiming primarily at comparing the experience gained by the two countries' information societies, the event was imbued with a spirit of collaboration and mutual search for common opportunities.

Then, from the middle of the 70s, the countries of the pursuing bunch started to regain consciousness, particularly Canada, Sweden and Australia, who found their way to the information society through the development of telecommunications (which was highly important, due to their geographical capabilities, too) involving an increase in penetration and advancement in the world of applications.

And what about Europe? The most important thing for the European Community's predecessor organizations had always been to make use of the experience, and through its own development performance, follow the footsteps of the other two world economic centers, the United States and Japan. Yet, strategic planning for the information age only commenced at the actual beginning of a continent-wide joining of forces and, in particular, subsequent to the establishment of its substantial institutional structure in the middle of the 90s. Although OECD's economic think-tank had already raised the idea of a global information society (GIS) following scientists of the "academic sector" at the end of the 60s, it was only in 1978, that the ministerial council of the common market countries launched a five-year pilot program, consisting of three major fields including the information society, and employing more than a dozen research groups. And even then, information technology had to wait until the mid-80s to take its position among these programs.

In the meantime, however, the revolution of personal computers, office automation and consumer electronics took place, and instead of the previously predicted tourism industry, it was information and communication technology (ICT) which by the end of the 80 s had become the leading sector worldwide, enabling the slices of the technology-based business cake to swell - if not in equal proportion, at least permanently. 
Therefore, while the markets and profits of the business forms founded on the latest technology showed relative growth as compared to earlier levels, thanks to the absolute growth of the latter, only rival manufacturers of certain product types within the same system sectors (semi-conductor producers, PC producers, software companies, system integrators) actually came into conflict with each other.

This explains why, after a while, the market-leading United States "yielded" dominance in the manufacturing of certain basic electronic components to Japan, and also why this imaginary torch was passed on after a short period to smaller "tigers", especially South Korea, which at that time was developing its semiconductor production through government intervention, as well as to Taiwan, then making headway in the manufacturing of several computer peripherals. This is further attributable to the fact that, by that time the United States had begun focusing on securing its dominant position in "third generation" products and services, leaving some of the key positions of the "second generation" to Japan through a peculiar division of labour. This global division of labour was defamed at the beginning of the $90 \mathrm{~s}$ when it became clear that national information and communication industries would require global markets to achieve sustainable growth, together with all the consequences.

Such expansion in size required an unprecedented concentration of capital, effective and economical entry into the market demanded a new standard of product and service integration, while flexible and unbridled expansion to external markets needed comprehensive liberalization and supranational regulation standards. This explains the overwhelming wave of mergers and buying-ups we have experienced among both traditional and new players from the information, telecommunications and media industries since the beginning of the $90 \mathrm{~s}$. And that is also the reason why former "top" companies are forced to leap technological system levels to survive (see, for example, Microsoft's "strategic" shift toward network content provision, or the "strategic" opening of the formerly reclusive IBM). This interprets the return of the need for the "global" feature in information infrastructure, this drives governments to be the "lobbyists" for the necessary political conditions for business expansion, and this makes the buzzword "global information society" a hollow phrase which, in the political marketing of the beneficiaries of transformation, is intended to bridge structural inequalities and the widening divide, while in fact leading to the current phase of information society strategies. 


\section{THE DECADE OF COMPREHENSIVE NATIONAL INFORMATION STRATEGIES: sprinting into the future, winners and losers (1992-2002)}

Strategists of the multicultural, yet strongly authoritarian island of Singapore were considering the following at the beginning of the 90s: what is our strongest capability that we could "enhance" with the help of up-todate information technology? If we can be successful in this field, which other fields require further information investment to enable us to "generate" new competitive advantages in addition to "traditional" ones?

It was relatively easy to address the former challenge. Singapore is a transit country that has been one of the prominent harbors of intercontinental sea trade for at least 150 years. The foremost thing therefore was to win the competition among Asian seaports - but how? They should provide the most professional and fastest service. And they did. The optical readers of the deepwater Singapore harbor (PSA, Port of Singapore Authority) can receive the necessary information, even about approaching ships, and code their containers. Then, with the help of professional crane operators, they carry out trans-shipment precisely, and at lightning speed. The accelerated customs procedure significantly decreases the waiting period per ship, so more and more companies have found it worthwhile to choose Singapore as their logistic hub. That is to say, the fundamentals were given on which the next stage of development could be constructed: to wire the population into a seamless network, to generate information-industrial expansion focusing on niche markets, and to empower a research and development potential of international standard. That's the way the 1992 Singapore "Intelligent island" program, the "father of all information strategy programs" (or new generation information society competitiveness strategies), has come into being (A Vision of an intelligent island. IT 2000 report).

Since that time, nearly fifty national-scale programs have been devised following more or less similar logic and considerations. The successful strategies either evolved or "cropped up" from within traditional information-industrialization and computerization programs (and the institutions managing them), or emerged as a result of individual government (typically ministry of finance) initiatives. The former model tends to be characteristic of Asia, while the latter, with all its advantages and shortcomings, is generally seen in Europe.

The "Asian model" is inclined to proceed organically without need of new institutions, but its synthesis, the representation of social aspects, has remained rather an off chance for a long period, due to a technology-bound form of operative planning. The European model, which relies for coordination on the market instead of government agencies with a monetary 
approach to information strategies, preserves traditional sector boundaries better, yet its comprehensive features are weaker [Rodrigues, 2001]. All things considered, there are a number of similar features even between information strategies of faraway countries.

"Information strategy" means the new quality, which emerged at the beginning of the $90 \mathrm{~s}$, of political planning on various levels: national or international-regional-federal [Evans-Wurster, 2000]. The characteristic separating information strategy from its progenitors, is that information strategy raises the development of information infrastructure, the "informatization" of certain subsystems of the society and information industry development policy (IT-industry policy), out of their functions within their own sectors and, by uniting them, makes a homogenous base for long-term planning. In contrast to the former purely "coordinative" relationship, information strategy, as a central participant, adjusts the main segments of education policy, the development of telecommunication, science policy and the economy of human resources to its own targets and tasks [See Z. Karvalics, 1998].

The elaborateness and sophistication of different information strategies is extremely various. The bulk Canadian basic document is orbited by dozens of satellite-program booklets, the comprehensive Finnish strategy is accompanied by a similarly detailed strategy devised only for the educational system, while the Polish or Philippine basic documents consist of just a couple of pages. Similarly, there is a wide variety of genres: beside the precisely elaborated Japanese plans, which break down the tasks into year-long phases, the Australian strategy is content with the mere description of four possible development scenarios. Besides recommendation-like analyses (such as Gerard Théry's "Report" in France, referred to as an information strategy) we can find some countries planning implementation with an almost military discipline (e.g. South Korea). Some countries (Vietnam, Norway) plan only for five years (about until the millennium), while others, Malaysia and Japan, target 2020 and 2015 respectively.

Essentially, national information infrastructure (NII), including government information infrastructure, is the core aspect functioning as a development initiator to facilitate ideas and expectations on the social level. In consequence of the substantial uniformity of technology, national characteristics hardly appear in such programs, which review the ITpotential of healthcare, education, research \& development and other fields as routinely as though they were only homework. The "teleological aspect", which deals with all these only as a tool to achieve its comprehensive vision, rarely appears: Japan, with its "intellectually creative society" program, practically sets the objective of a cultural paradigm shift, Malaysia intends 
to join the most developed countries through grandiose developments, while others see their perspective in creating a new quality of "welfare".

Direct objectives are relatively simple: job creation, cost reduction, increased efficiency, better practices, greater publicity, satisfied citizens. All these mainly involve similar tasks, without priorities: standardization, integration, and implementation. In order to launch local experiments, pilot projects, governments principally rely on private capital and local resources [Z. Karvalics, 1998].

It is interesting to see if we can measure the success of information society strategies in the language of numbers, based on the readiness methodology of IDC (www.idc.com). If we examine a list based on identical standpoints (the first Information Imperative Index, 1996) the updated data five years later (which is called Information Society Index in 2000), we will be able to draw conclusions through interpreting the changes (see Table 2 and Table 3 with the 2002 rankings). All the more so since the boom of the Internet and mobile telephony coincides exactly with that frame, so the selected period is not interrupted by any technological shifts.

In five years, the world slowly closes up the ranks of top information society indicators (the four basic indicators are: computers, Internet, information, society - reflecting all the relevant aspects of the information society). While in 1996 only two countries belonged to the first category (USA and Sweden), by 2000 it was 13 . Five years ago Hungary's 1500 points $\left(27^{\text {th }}\right.$ place $)$ was only enough for the third category, but by now we stand $28^{\text {th }}$ at the end of the second category with 2130 points, like the Czech Republic (we stand last but one in group B preceding Greece). That is to say, we skipped a class so that we fell back one place. Moreover, "tiny" Estonia, the Baltic States, Slovenia, Slovakia, Malta, Cyprus, and Iceland, while possessing excellent indicators are not represented on the list at all. All these clearly suggest a more comprehensive tendency: information society indicators slowly "permeate" societies, and the gradual increase of points, at the same time, indicates a sort of equalization or levelling.

In case of the top thirty countries we experience an average of 6-700 points of growth in five years. The "race" is very intense, especially in the upper region. In many cases, even better-than-average point increase proved to be insufficient to prevent "backsliding": Israel dropped back one position despite its 915 -point growth, France fell 2 places despite 836 points plus, Austria ranked one place worse notwithstanding its 757-point growth.

Meanwhile a point increase close to the average of the leading countries could even cause significant advances. Malaysia's 593 points resulted in 2 places forward, China's 580 points meant 4 positions upward, Turkey jumped 3 places by 564 points plus, while 380 points also slid the Philippines up 3 positions. "Negative performance" was presented only by 
the United States (minus 66 points and thus losing first place) and NewZealand (minus 74 points and falling back 8 positions), which clearly demonstrates that, in comparison to the high levels achieved earlier, it is difficult to see the way forward. But if we scrutinize some of the considerable upward movements, we will see that only those countries that were renowned for the determination and awareness of their information society policies were able to attain above-average growth throughout five years!

The dynamic Singapore leaped ahead 5 places by 1498 additional points, Ireland and Holland jumped 4 places by 1222 and 1129 points respectively, while Japan and Taiwan in turn sprang 3 positions forward by 1123 and 1107 points. Sweden's 1009 points were enough to take the leading position in the ranking, pushing the United States off the top. Among the leaders it is interesting to note the 2-place advances of Belgium, Portugal and Finland by their approx. 900 points plus. It is more than interesting that out of all countries Romania has come the longest way upwards to $31^{\text {st }}$ place from $42^{\text {nd }}$ with its 817 point advance (only to fall 3 places later in $2001 \ldots$ ).

The message of the 2002 rankings is the sharpening struggle among the pursuers (5-13 rankings) and the highly motivated "leap-froggers" (32-41). It seems to be obvious, that a real chance for a perceptible improvement implies a higher awareness rate, which in turn engenders an informationfocused development program. This accelerates IT-diffusion, and makes the density indicators higher and higher. But does it mean that the "middle" and the "end" are hopeless cases? What about the adequate strategies of the lowranked countries? What is the answer if the question is: "informatization, what's it for"? And the most worrying side of the problem is the possible follow-up of this competitive struggle: how do we imagine the postinformation (society) race?

\section{CONCLUSIONS}

- We can detect various forms of information- and knowledge-centered competitive "games" during the "first" and "second wave" periods of our History.

- If we believe in the "readiness" measurements, the world's leading countries are making fast progress in the development of their information societies in an intensified race. During the most recent period, some North-Western European and South-East Asian states have emerged as top tier countries, while we can detect the serious advantage of the small countries. 
- Although even the poorest countries can display signs of growth, nonetheless, their distance in points from the leaders still widens. The slowdown of declination is expected to occur in the second part of the next five-year period, but the narrowing tendency of the divide may only commence during the cycle after that. The only real "re-versioners" to jump are Malaysia, Turkey and South Africa.

- A consciously planned, systematic information strategy devised on the level of government programs is not a marketing effort, but an "investment in the future" capable of producing real results. Otherwise, information society building success is not "time-proof", unless there are permanent development cycles, driving the process onto the next step and steps beyond.

\section{REFERENCES}

Assmann, Jan (1992): Das kulturelle Gedachtnis. Schrift, Erinnerung und politische Identitat in frühen. Hochkulturen Verlag C.H. Beck, München, 1992

Chandler, Alfred D.Jr. - Cortada, James W. (eds.): A nation transformed by information. How information has shaped the United States from Colonial times to the present, Oxford University Press, Oxford, New York

Dedijer, Stefan (1968): Early migration In: Adams, Walter (ed.): The Brain Drain, London, pp. 9-28

Evans, Philip - Wurster, Thomas S. (2000): Blown to bits. How the new economics of information transforms strategy, Harvard Business School Press, Boston

Innis, Harold. A (1950): Empire and Communication, University of Toronto Press Innis, Harold. A (1951): The Bias of Communication, University of Toronto Press

Klaniczay, Tibor (1993): A magyarorszagi akademiai mozgalom elotortenete (The Pre-History of the Hungarian Academia), Balassi Kiadó, Bp. p.8.

Kopátsy, Sándor (1989): A civilizacios orokseg megnovekedett jelentosege (The emerging importance of the civilization heritage) In: Trendek magyar modra OMIKK, pp. 94-105.

Mann, Charles C. (1995): Email by any other name... Inc. Technology Summer 1995, Vol.17. Issue 4, p54.

Paquet-Sévigny, Thérése 1997: Convergence of Visions: a condition of effective partnerships in a multilateral and multicultural environment In: Info-ethics. Conference papers Monte-Carlo UNESCO, 1997

Radioamateur, (1929): A summary of the list. (In Hungarian) Rádióamator Vol 4. Issue 9. Sept. p. 502.

Rodrigues, Maria Joao (2001): The New Knowledge Economy in Europe. A Strategy for International Competitiveness and Social Cohesion. Edgar Elgar Publishing, Cheltenham, Northampton

Vekerdi, László (1971): A "tortenelem elotti idok" muveszete (The Art of Prehistory) In: Befejezetlen jelen Magveto, Bp.

Z. Karvalics, László (1998): Information Society Visions: from the early utopias to the adequate government-level strategic planning methods In: Informatization 
et anticipations. Information Society: Looking ahead. Proceedings, Strasbourg, France, June 10-12 pp. 63-74.

1 For the relevance of the information history-based overview, see ChandlerCortada (2000).

2 See Assmann (1992) adapted from Echlich and Lotman.

3 In the 30s, Robert Albion, an American economic historian, used his "spaceannihilating communication revolution" concept to deduce the whole American industrial revolution from communication technology as the "single and most important factor".

4 The Japanese postal service, which always operated at considerable loss, only received sufficient funds at the beginning of the $20^{\text {th }}$ century, during the period of Japanese imperial expansion. By the way, in Southeast Asia, the three citystates of Taiwan, Singapore and Hong Kong had already taken their places among the top three in information infrastructure (especially via their prominent positions gained along cable-laying routes) at the end of the $19^{\text {th }}$ century, besides Japan and Korea. We should not disregard this issue when we attempt to reconstruct their later successful information society stories.

5 Charles C. Mann, astonished by the fact that in 1890 the old Verdi and his librettist, Arrigo Boito often wrote 3-4 letters daily to each other, is inclined to recognize the archetype of email, which praises the advanced postal service of North Italy (especially Milan, proud of its five delivery cycles each day). (Mann, 1995) Milan, by the way, claimed to have the most advanced postal service even in the Middle Ages: they indicated the date (day and hour) of departure and delivery on letters, and they also used "up-to-date privacy policies" (the violation of the secrecy of correspondence was punished with death). It was the Berlin dispatch-tube launched in 1876 that achieved unsurpassable speed with its 15-minute delivery speed.

6 US Congress first voted to allocate $\$ 30,000$ in March 1843 to drive further development.

7 The main ambition of the German Postmaster General Stephan, the leading ideologist and director of "telephony", however, was not to establish networks in big cities, but to connect smaller townships to telegraph-stations in order to be able to deliver telegraph messages from there via the much cheaper telephone. While in 1879 , America had 20 city telephone networks, Berlin only opened its first one in 1881, yet, by that time there had already been about 1200 smaller rural telephone offices operating in Germany (the prototype of Infobahn itself!).

8 Note that the German people's wireless set program of the 30 s contained the combined elements of the broadcasting network and the industry development program, which promoted the mass production of cheap end-devices. The Russian solution based on wired broadcasting was also very similar. 
9 Just to "run through" the story: by the beginning of the $20^{\text {th }}$ century, the public libraries of the United States became the epicenter of development, making the fact exciting that the Universal Decimal Classification "software" appears and spreads as an American development at the end of the $19^{\text {th }}$ century.

10 The life of humanists is nothing else than a constant colloquium." Eugenio Garin cited by Klaniczay (1993).

11 Organized education, however, is an older phenomenon than government itself. According to Vekerdi (1971), the "perfection of prehistoric cave pictographs in itself is enough to suggest a sort of artist education"... based on the sketch stones, the several followers appearing next to the master, and the corrections made by the master...

12 The ranking of "Italy $-15-17^{\text {th }}$ century - German-speaking world $18-20^{\text {th }}$ century - United States of America - from the mid-20 $0^{\text {th }}$ century" outlines the "competition axis" of advanced knowledge production. It is noteworthy that American universities took the lead only much after attaining a leading position in infrastructure indicators. 
Table 1: Number of radio transmitting stations in 1929 [Radioanateur, 1929 ]

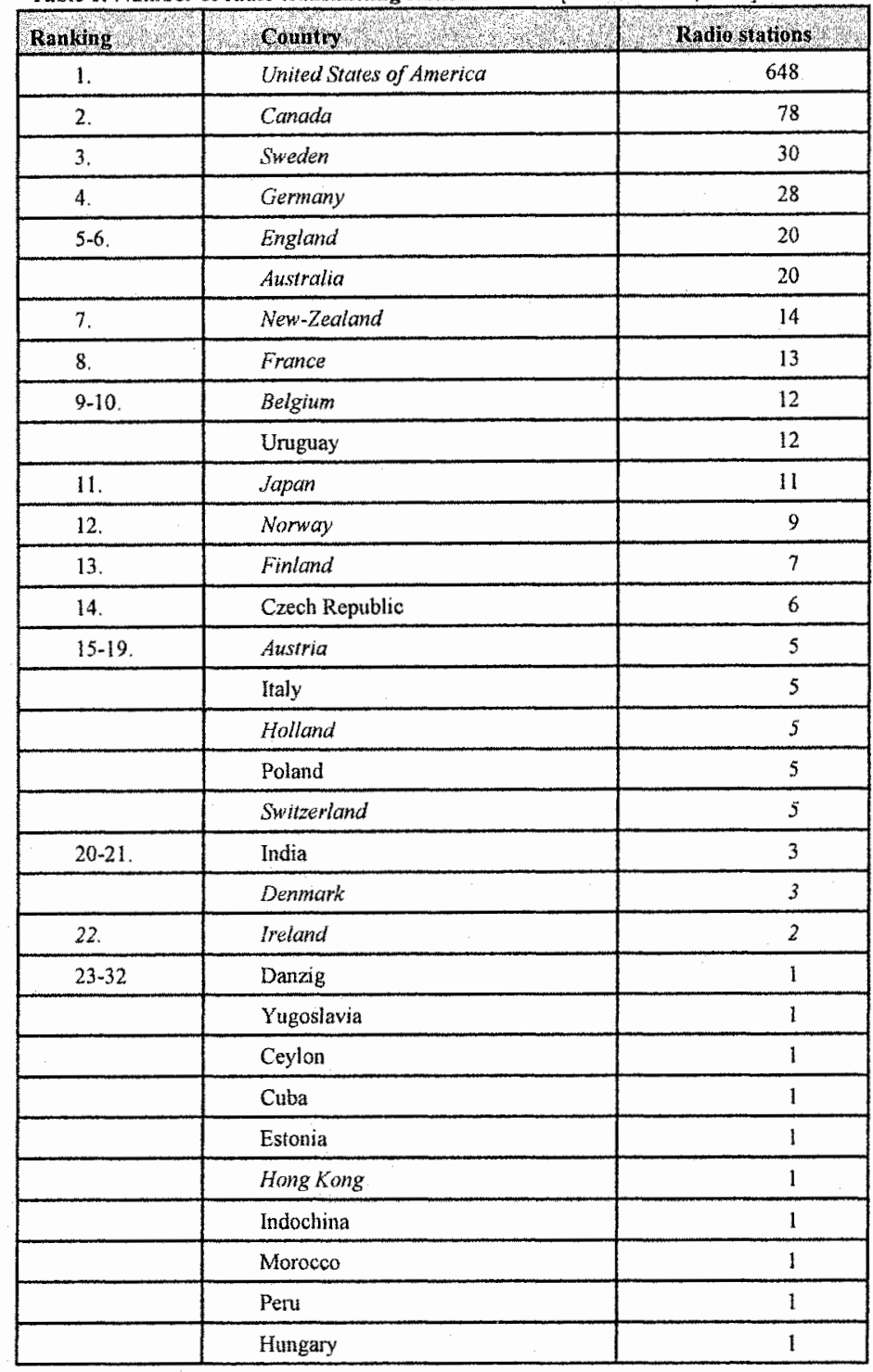


Table 2. The information society points competition: development rankings by World Times, 1996 and 2000

\begin{tabular}{|c|c|c|c|c|c|}
\hline \multicolumn{3}{|c|}{ Information Imperative Index 1996} & \multicolumn{3}{|c|}{ Information Society Index 2000} \\
\hline Rank & Country & Points & Rank & Country & Points \\
\hline 1 & United States & 5,107 & 1 & Sweden & $5,062 \uparrow$ \\
\hline 2 & Sweden & 4,003 & 2 & Unites States & 5,041 \\
\hline 3 & Denmark & 3,842 & 3 & Finland & $4,577 \uparrow$ \\
\hline 4 & Norway & 3,755 & 4 & Norway & 4,481 \\
\hline 5 & Finland & 3,722 & 5 & Denmark & 4,336 \\
\hline 6 & Australia & 3,704 & 6 & Canada & 4,336 \\
\hline 7 & Canada & 3,494 & 7 & Netherlands & 4,230 \\
\hline 8 & Switzerland & 3,459 & 8 & Switzerland & 4,174 \\
\hline 9 & New Zealand & 3,363 & 9 & Australia & 4,129 \\
\hline 10 & United Kingdom & 3,148 & 10 & Japan & $4,093 \uparrow$ \\
\hline 11 & Netherlands & 3,099 & 11 & Singapore & $4,014 \uparrow$ \\
\hline 12 & Germany & 2,970 & 12 & United Kingdom & 3,807 \\
\hline 13 & Japan & 2,970 & 13 & Germany & 3,558 \\
\hline 14 & Hong Kong & 2,893 & 14 & Hong Kong & 3,484 \\
\hline 15 & Austria & 2,640 & 15 & Belgium & 3,419 \\
\hline 16 & Singapore & 2,516 & 16 & Austria & 3,397 \\
\hline 17 & Belgium & 2,475 & 17 & New Zealand & 3,289 \\
\hline 18 & France & 2,296 & 18 & Taiwan & $3,177 \uparrow$ \\
\hline 19 & Israel & 2,225 & 19 & Ireland & $3,144 \uparrow$ \\
\hline 20 & Italy & 2,070 & 20 & Israel & 3,140 \\
\hline 21 & Taiwan & 2,053 & 21 & France & 3,140 \\
\hline 22 & Korea & 2,008 & 22 & Korea & 2,931 \\
\hline 23 & Ireland & 1,922 & 23 & Italy & 2,703 \\
\hline 24 & Spain & 1,872 & 24 & Spain & 2,533 \\
\hline 25 & UAE & 1,618 & 25 & UAE & 2,301 \\
\hline 26 & Czech Rep & 1,528 & 26 & Portugal & $2,199 \uparrow$ \\
\hline 27 & Hungary & 1,500 & 27 & Czech Republic & 2,130 \\
\hline 28 & Greece & 1,377 & 28 & Hungary & 2,130 \\
\hline 29 & Portugal & 1,301 & 29 & Greece & 2,033 \\
\hline 30 & Argentina & 1,215 & 30 & Poland & 1,808 \\
\hline 31 & Chile & 1,181 & 31 & Romania & $1,679 \uparrow$ \\
\hline 32 & Poland & 1,159 & 32 & Chile & 1,677 \\
\hline 33 & Bulgaria & 1,069 & 33 & Argentina & 1,651 \\
\hline 34 & Venezuela & 1,050 & 34 & Costa Rica & $1,635 \AA$ \\
\hline 35 & South Africa & 1,043 & 35 & Malaysia & $1,583 \uparrow$ \\
\hline 36 & Russia & 1,041 & 36 & Bulgaria & 1,578 \\
\hline 37 & Malaysia & 990 & 37 & Panama & 1,539 \\
\hline 38 & Brazil & 961 & 38 & South Africa & 1,537 \\
\hline 39 & Costa Rica & 952 & 39 & Venezuela & 1,491 \\
\hline 40 & Panama & 918 & 40 & Russia & 1,444 \\
\hline 41 & Mexico & 871 & 41 & Saudi Arabia & 1,362 \\
\hline 42 & Romania & 862 & 42 & Brazil & 1,354 \\
\hline 43 & Saudi Arabia & 850 & 43 & Ecuador & 1,314 \\
\hline 44 & Colombia & 755 & 44 & Mexico & 1,286 \\
\hline 45 & Thailand & 725 & 45 & Turkey & $1,259 \uparrow$ \\
\hline 46 & Ecuador & 695 & 46 & Colombia & 1,136 \\
\hline 47 & Jordan & 695 & 47 & Philippines & $1,012 \uparrow$ \\
\hline 48 & Turkey & 695 & 48 & Thailand & 1,010 \\
\hline 49 & Peru & 651 & 49 & Jordan & 942 \\
\hline 50 & Philippines & 632 & 50 & Egypt & 931 \\
\hline 51 & Egypt & 586 & 51 & China & $915 \uparrow$ \\
\hline 52 & India & 435 & 52 & Indonesia & 888 \\
\hline 53 & Indonesia & 387 & 53 & Peru & 877 \\
\hline 54 & Pakistan & 371 & 54 & India & 871 \\
\hline 55 & China & 335 & 55 & Pakistan & 719 \\
\hline
\end{tabular}


Table 3. The 2002 IDC information Society Index with sub-categories

\begin{tabular}{|c|c|c|c|c|c|c|c|c|c|c|}
\hline \multirow{2}{*}{$\frac{C o u n t r y}{\text { Sweden }}$} & \multirow{2}{*}{$\begin{array}{l}\text { Rank } \\
\text { in } \\
\frac{2000}{1}\end{array}$} & \multicolumn{2}{|c|}{$\begin{array}{l}\text { Computer } \\
\text { Score }\end{array}$} & \multicolumn{2}{|c|}{$\begin{array}{l}\text { Internet } \\
\text { Score }\end{array}$} & \multicolumn{2}{|c|}{$\begin{array}{l}\text { Information } \\
\text { score }\end{array}$} & \multicolumn{2}{|c|}{ Social Score } & \multirow{2}{*}{$\begin{array}{l}\text { Score } \\
2002 \\
7,087\end{array}$} \\
\hline & & 815 & 6 & 2,622 & 1 & 2,265 & 8 & 1,385 & 4 & \\
\hline Norway & 2 & 812 & 7 & 2,312 & 4 & 2,267 & 7 & 1,542 & 1 & 6,932 \\
\hline Switzerland & 7 & 849 & 4 & 2,478 & 3 & 2,215 & 11 & 1,137 & 12 & 6,679 \\
\hline United States & 4 & 1,362 & 1 & 2,004 & 10 & 2,167 & 14 & 1,099 & 17 & 6,632 \\
\hline Denmark & 5 & 743 & 13 & 2,170 & 7 & 2,486 & 3 & 1,213 & 10 & 6,612 \\
\hline Netherlands & 10 & 770 & 12 & 1,898 & 12 & 2,490 & 2 & 1,317 & 7 & 6,474 \\
\hline UK & 6 & 782 & 10 & 2,224 & 6 & 2,292 & 5 & 1,139 & 11 & 6,437 \\
\hline Finland & 3 & 671 & 14 & 2,132 & 9 & 2,283 & 6 & 1,337 & 6 & 6,422 \\
\hline Australia & 8 & 797 & 9 & 2,302 & 5 & 1,892 & 22 & 1,350 & 5 & 6,341 \\
\hline Taiwan & 18 & 581 & 19 & 1,852 & 14 & 2,602 & 1 & 1,257 & 9 & 6,292 \\
\hline Hong Kong & 15 & 868 & 3 & 1,770 & 16 & 2,229 & 10 & 1,388 & 3 & 6,255 \\
\hline Japan & 11 & 819 & 5 & 1,754 & 17 & 2,176 & 12 & 1,394 & 2 & 6,143 \\
\hline Singapore & 9 & 800 & 8 & 2,504 & 2 & 1,953 & 21 & 810 & 33 & 6,067 \\
\hline Canada & 12. & 1,001 & 2 & 2,140 & 8 & 1,805 & 25 & 1,093 & 18 & 6,039 \\
\hline Germany & 13 & 623. & 17 & 1,902 & 11. & 2,248 & 9 & 1,134 & 13 & 5,907 \\
\hline Austria & 14 & 660 & 15 & 1,884 & 13 & 2,175 & 13 & 1,123 & 15 & 5,842 \\
\hline Poland & 30 & 247 & 37 & 436 & 35 & 1,359 & 30 & 834 & 32 & 2,875 \\
\hline Argentina & 31 & 325 & 31 & 450 & 33 & 1,160 & 33. & 841 & 31 & 2,776 \\
\hline Chile & 33 & 314 & 33 & 436 & 36 & 1,038 & 39 & 844 & 30 & 2,632 \\
\hline Panama & 37 & 377 & 27 & 422 & 37 & 1,067 & 37 & 765 & 35 & 2,631 \\
\hline Bulgaria & 34 & 169 & 46 & 308 & 44 & 1,230 & 32 & 919 & 28 & 2,625 \\
\hline
\end{tabular}

The ISI includes 23 indicators measuring the capacity of a nation's citizenry to exchange information internally and externally.

Computer infrastructure: PC installed per capita/ Home PC's shipped per household/ Government and commercial PC's shipped per professional workforce/ Education PC's shipped per student and faculty member/Percentage of networked PCs/Software and hardware spending

Internet infrastructure: Amount of eCommerce/ No. of Internet home users/ No. of Internet education users

Information infrastructure: Telephone lines per household/Telephone faults/lines /Cost of local telephone call/ Television owneship per capita/ Radio owneship per capita/ Fax ownership per capita/ Cellular phones per capita/ Cable subscribers

Social infrastructure: Secondary school enrollment/Tertiary school enrollment/Newspaper readership/ Press freedom/ Civil liberties 


\section{PART 2 - THE INFORMATION SOCIETY: ISSUES OF MAJOR CONCERN}

